\title{
CONTESTED INTERPRETATIONS OF INDONESIA'S INTERNATIONAL LEADERSHIP IN THE FOREIGN POLICY OF PRESIDENT SUSILO BAMBANG YUDHOYONO AND JOKO WIDODO
}

\author{
Aleksius Jemadu ${ }^{1}$ and Floranesia Lantang ${ }^{2}$ \\ ${ }^{1,2}$ Department of International Relations, Faculty of Social and Political Sciences, \\ Pelita Harapan University \\ J1. M.H. Thamrin Boulevard, Tangerang, Banten 15811, Indonesia \\ 1aleksius.jemadu@uph.edu; ${ }^{2}$ floranesia.lantang@uph.edu
}

Received: $21^{\text {st }}$ June 2021/ Revised: $03^{\text {rd }}$ September 2021/ Accepted: 03 ${ }^{\text {rd }}$ September 2021

How to Cite: Jemadu, A. \& Lantang, F. (2021). Contested interpretations of Indonesia's international leadership in the foreign policy of President Susilo Bambang Yudhoyono and

Joko Widodo. Journal of ASEAN Studies, 9(2), 199-217.

https:/doi.org/10.21512/jas.v9i2.7478

\begin{abstract}
The research aimed to examine the Indonesia's international leadership on foreign policy throughout the period of President Susilo Bambang Yudhoyono and President Joko Widodo, who have developed different conceptualizations of foreign policy. It ultimately affects the way each of them makes an interpretation of what Indonesia should do with its international leadership. The research built a solid and rich theoretical framework by consulting on previous research focusing on factors that affect the nature of international leadership especially regarding the role of the individual styles of a state leader. The research had two illustrations or brief case studies, namely, the promotion of democracy and human rights and the initiative of promoting the Indo-Pacific cooperation with a special emphasis on the period of President Joko Widodo. The research finds that he has changed the nature of Indonesia's international leadership to make it fit into his domestic agenda. While President Susilo Bambang Yudhoyono tends to make Indonesia's international leadership as an essential part of his rigorous effort to build a post-authoritarian identity for a democratic and stable nation, President Joko Widodo prefers to make his foreign policy serve the accomplishment of his domestic priorities. The research concludes that Indonesia's international leadership is much contingent upon individual preferences of the presidents in both formulating their policies as well as the implementation. Moreover, the research comes up with constructive ideas which might be useful to strengthen Indonesia's international leadership in the future.
\end{abstract}

Keywords: Indonesia, foreign policy, international leadership, democracy, ASEAN, Indo-Pacific 


\section{INTRODUCTION}

Research on the role of state leaders in the characterization of Indonesia's international leadership has been previously conducted by various authors. Focusing particularly on foreign policy driven by Soeharto's development, Suryadinata (1996) argues that Indonesia's international behavior was very much dictated by the ongoing dynamics of international politics during the two presidents' period in power. Although Indonesia had limited national capabilities to have an effective influence over the course of international events during their respective periods of government, both leaders had enough self-confidence to assert that Indonesia deserved to be recognized as a leading participant in regional and global affairs. Indonesia became one of the founding members of ASEAN in 1967 and enjoyed a recognition as an informal regional leader of the association in the 1970s until 1980s. Karim (2021) focuses on how President Susilo Bambang Yudhoyono (Yudhoyono, hereafter) tried to legitimize Indonesia's international leadership role by referring to Indonesia's historical experience in conducting such role and using international expectations to ensure domestic support for the president's foreign policy endeavor. Thus, Karim's argument points to the key role of a state leader in determining the nature of his foreign policy endeavor.

Academics provide different answers to two important questions: 1) Whether Indonesia has the ability to carry out its international leadership; and 2) Whether there is real evidence that Indonesia plays such role. Reid (2012), for instance, draws our attention to some internal challenges like corruption, weak law enforcement, and bureaucratic inefficiency that need to be resolved if Indonesia wants to have a bigger influence in international relations. Unlike Reid, Acharya (2014) argues Indonesia had succeeded in accomplishing three policy agendas of development, democracy, and stability in such a way that it deserves to be considered as an emerging democratic power of Asia with a promising prospect in the future. Roberts, Habir, and Sebastian (2015) focuses on the idea of how Indonesia had risen as an emerging power with all the constraints and opportunities it had to face in its external environment. Since their research only covers Indonesia's foreign policy until 2014, it is considered essential to examine its change and continuity especially since President Joko Widodo (Widodo, hereafter) came to power in 2014. Although the research covers the periods of President Yudhoyono and President Widodo, more extensive analysis will be provided to the latter with the purpose of demonstrating how a changing conceptualization of Indonesia's international leadership has affected the way it is enacted.

Shekhar (2018) has developed the most recent analysis of the correlation between Indonesia's rising power and its international ambition to play a leading role in regional and global politics. However, Shekhar's depiction of Indonesia as an Indo-Pacific power raises a question whether there is indeed convincing evidence that Indonesia harbors such a strong intentionality to engage in a contestation of power that is going on in the region. A more realistic interpretation would argue that Indonesia's declaration as a global maritime fulcrum is mainly meant to protect its own territorial waters without any explicit ambition to be an active and assertive player in the strategic competition among great powers. To say that Indonesia has an explicit ambition to become a regional maritime power would contradict the reality of its material or military power on which such ambition could be based. 
It follows that there is a need to demonstrate through empirical research the circumstances under which Indonesia can show its capability to lead, the real conduct of such leadership, and conditions which might lead to its withdrawal from such leadership and explain its reluctance to act. The research also seeks to find out how President Yudhoyono dan President Widodo, as well as their foreign policy conceptions might characterize the nature of Indonesia's international leadership. It is argued that the conceptualization of Indonesia's international leadership by each president matters to the extent that such international leadership is not static but significantly dynamic depending on what meaning the state leaders want to attach to such foreign policy endeavor.

\section{THE ARGUMENT AND THE THEORETICAL CONCEPTS}

From the perspective of the study of foreign policy and international relations, the research is more concerned with the importance of individual level of analysis and less about the state and international system levels of analysis in explaining how the activity of international leadership by a state operates in reality (Viotti \& Kauppi, 2014). The use of the concept of international leadership in this research refers to an effort by a state to influence other states, so they might achieve their common goals. According to Destradi (2010), the concept of international leadership is different from empire or hegemony since it gives more emphasis on the mobilization of normative or ideational resources instead of capitalizing on material resources or military preponderance. Such concept is quite useful in analyzing Indonesia's foreign policy as it seeks to make a projection of its influence not only among ASEAN countries but also beyond Southeast Asia. Thus, all along the Indonesian leaders are aware of Indonesia's primacy in terms of geographical size and population in the region but how they translate such awareness into foreign policy orientation varies from one president to another. Following Destradi's categories of "leader-initiated leadership" and "followerinitiated leadership", the research aims to find out how President Yudhoyono and President Widodo choose the suitable type of leadership for their respective government. It will be argued that the choice made by each of these state leaders is contingent upon how each of them conceptualizes Indonesian foreign policy and utilizes it to accomplish a set of predetermined policy priorities. The determinant role of foreign policy elite in Indonesia's promotion of democracy and human rights is also highlighted by Karim (2016) who challenges the idea that such promotion is rooted in a solid foundation of state identity. The research also takes advantage from results by Breuning (2007) who utilizes the concept of leadership trait analysis with three important elements including attitude towards constraints, openness to new information, and motivation. By using the three elements, a set of guiding questions can be made, for instance: 1) How do President Yudhoyono respond to the constraints created by the great powers in Indonesia's external environment? 2) Is President Widodo open to new information or does he stick to the primacy of his domestic agenda? 3) What is President Widodo's motivation in promoting Indonesia's hedging strategies towards the US and China?

It is quite evident that the way President Widodo conceptualizes Indonesia's international leadership remains consistent with his political pragmatism and the primacy of 
his domestic accomplishment. The president's influence in the foreign policy making represents what Mintz and DeRouen Jr (2010) call cognitive consistency in the sense that his prior images and beliefs consistently determine what is important in responding to the complexity of his external environment. Similar recognition of the importance of leader's personal decision-making style can be found in Beasley et al. (2013) suggesting that leaders can be selective in sticking to the information that fits into their strongly held belief systems. Such conceptualization of international leadership may explain the way President Widodo has promoted democracy and human rights in the region with its emphasis on the imperative of good governance to increase Indonesia's national competitiveness, Indonesia's initiative in the promotion of the ASEAN Outlook on the Indo-Pacific, Indonesia's hedging strategies towards China and the US, and Indonesia's reluctance to go the extra mile in pressurizing the military regime in Myanmar to accept ASEAN's policy proposal to resolve the political crisis in that country. Future uncertainties regarding the economic recovery in the post-pandemic COVID-19 may only reinforce such foreign policy direction at least until 2024 when President Widodo ends his second term in office. Under such domestic and external circumstances, it might be relevant here to adopt three important concepts introduced by Breslin (2017), which are willingness, capability, and acceptance for the purpose of explaining the nature of Indonesia's international leadership in ASEAN. We cannot take for granted that Indonesia has the willingness to lead on any issue unless it is directly tied to its own immediate interests. This is particularly the case under the pragmatism of President Widodo's presidency. With relatively limited material and military power, Indonesia's international leadership is characterized more by the mobilization of its ideational resources than material power. Finally, Indonesia's international leadership among ASEAN countries is made possible by the fact that other ASEAN members expect such regional leadership as long as Indonesia stands on the commonality of the interests of all ASEAN members vis a vis the great powers. Nabers (2010) affirms that international leadership cannot be separated from 'the wants and needs of followers' if it is meant to be effective.

As a pragmatic leader President Widodo will tend to perceive the emerging region of the Indo-Pacific with a narrative of economic interdependence in mind and avoid the idea of power politics by the great powers. There are, at least, three reasons why the idea of economic interdependence is more preferred than the narrative of power politics. First, in the context of economic interdependence, President Widodo wants to utilize trade and investment opportunities made available by the Asian economic powerhouses China, Japan, and India and make them serve his domestic priorities of building Indonesia's infrastructures. Second, considering Indonesia's limited material and military capabilities, it would be self-defeating to follow the narrative of a contestation of power. Not only will it destabilize the region, it will also weaken ASEAN's unity and solidity of which Indonesia is its traditional leader. Third, even if the great powers choose to continue with their power politics, President Widodo can capitalize on the credibility of Indonesia's tradition of independent and active foreign policy to play a mediatory role by which it could add more significance to its international leadership in the region. By using all the concepts related to the nature of Indonesia's international leadership, it is believed that there is a solid theoretical foundation to argue that President Widodo is not just a passive recipient of a foreign policy legacy from his 
predecessor President Yudhoyono. President Widodo actively reinterprets and redefines such legacy to suit his policy priorities which are ultimately meant to strengthen his performance legitimacy in the eyes of various domestic political constituents. With this argument, the research aims to challenge the idea that President Widodo is indifferent about Indonesia's tradition of international leadership in its foreign policy. The research applies explanatory methods for the analysis aiming to explain the causality between the cognitive and belief systems of state leaders and the way they practice it in a changing external environment (Howard, 2010). By connecting events in a meaningful way, the research is expected to produce useful insights about the nature of Indonesian's international leadership. The research uses various sources of evidence from newspapers, government reports, books, and journal articles to support the analysis.

\section{INDONESIA'S LEADERSHIP IN DEMOCRACY AND HUMAN RIGHTS}

When President Yudhoyono came to power in 2004 after Indonesia's first direct presidential election, he had two things in mind as far as the country's international leadership in the field of democracy and human rights. First, he aspired to instrumentalize Indonesia's democratic consolidation as an opportunity to leave behind the authoritarian past by replacing it with a new identity as a nation capable of upholding universal democratic principles and norms. Second, being the largest democracy in Southeast Asia, Indonesia aspired to spread democratic norms and principles through dialogue and exchange of experiences without any intention of imposing it on other states. Although President Yudhoyono's second agenda could only be materialized at the end of his first term through the establishment of Bali Democracy Forum (BDF) in 2008, it was quite evident that he has intention to make it a logical outcome of Indonesia's new identity as a new democratic country. President Yudhoyono seemed to realize that as Indonesia's first directly elected president, he had a personal mission to introduce Indonesia's new identity as a democratic country to the world.

In the eyes of President Yudhoyono there were several reasons why Indonesia could claim to be capable of setting a good example or model for the rest of Southeast Asia in upholding democratic values and human rights. First, Indonesia used to maintain its stability through the operation of an authoritarian government under President Soeharto. However, under his presidency, Indonesia had managed to consolidate its democracy by introducing a multi-party based presidential system. Thus, Indonesia's political model had shown to the rest of the region of Southeast Asia that authoritarian political system was not the only option to create political stability and achieve economic growth. On top of that, Indonesia's domestic stability had a positive impact on the stability of the whole region.

Second, as a nation with the largest Muslim population in the world, Indonesia set a good example of a workable compatibility between Islam and modern democracy. Such compatibility produced a positive co-existence between religious commitment and democratic rules of the game in the organization of political power. Moreover, while the democratic movements of the so-called Arab Spring in many Middle East countries had ended up in protracted sectarian conflicts and the return of the military regime like in Egypt, Indonesia as 
a Muslim-dominated nation, stood out as a stable democracy capable of peacefully managing its multi-ethnicity.

Third, as new democracy, Indonesia was also capable of combining coercive measures and cultural approaches to fight against terrorism. Considering that Southeast Asia had become a new area of operation for ISIS (Islamic State of Iraq and Syria) outside the Middle East, Indonesia's program of deradicalization could be a model to be emulated by other countries in Southeast Asia. Instead of relying solely on the security approach through the enactment of quite repressive legislation like Internal Security Act (ISA) in Malaysia and Singapore, being consistent with the progress of its democratic consolidation, Indonesia had chosen to make a balance between firm law enforcement and cultural approach through deradicalization of the terrorist convicts with full support from Islamic mass organizations like Nahdlatul Ulama and Muhammadiyah.

Fourth, Indonesia's success in resolving the separatist conflict in Aceh peacefully through the signing of the Helsinki Agreement in 2005 was a proof of the positive correlation between democratic consolidation at the center and the capacity to abandon military approach in resolving a separatist conflict in the region. Since the collapse of Soeharto's authoritarian regime in 1998, there had been an escalation of conflict in Aceh with the effect that in 2003 the Indonesian government under President Megawati Soekarnoputri, who was backed by the military, enacted martial law. With the direct election of President Yudhoyono in 2004, the Indonesian military reform made a significant progress, so the process could take place without any serious obstacle. Considering that separatist movements remain unresolved in places like Southern Thailand, Myanmar, and Southern Philippines, Indonesia's experience in Aceh can be a source of inspiration for future possibility of a peaceful conflict resolution. According to Destradi's categories (2010) concerning international leadership, the establishment of the BDF can be considered as Indonesia's initiative to set a good example of a democratic transformation that can be emulated by other ASEAN members. There were at least two main factors underlying Yudhoyono's prompt response to the issue of democracy and human rights in Myanmar. First, the Indonesian government could not put aside the internal pressures from the Islamic communities in Indonesia who sympathized with the sufferings of the Rohingyas. Second, there was an external pressure from countries in ASEAN and outside of the region as they expected Indonesia to lead the process of democratization in Myanmar. Dermawan, Purnama, and Mahyudin (2018) explain that Indonesia's policies to Myanmar aimed to show its ability in managing diversity, likewise internal conditions in the country. Certainly, there are other case studies that can be used to analyze Indonesia's role in promoting democracy and human rights during Yudhoyono's presidency. For instance, Alexandra and Basuki (2014) focus on the issue of migrant workers, the Rohingya case, and Indonesia's response to the Iranian sanction. An exhaustive exploration of possible case studies does not end here since being consistent with the main argument of the research, it is essential to highlight how each Indonesian state leader develops a distinct personal understanding of Indonesia's international leadership in his or her foreign policy implementation. 
While Yudhoyono's policy was mainly driven by his international activism, President Joko Widodo remains committed to his domestic priorities and does not seem to have a particular ambition in dealing with this regional issue. He did send humanitarian assistance to Myanmar but mainly for the purpose of responding to the demands of the Islamic opposition groups in Indonesia and not for changing Myanmar's political landscape. Similar thing can be said about President Widodo's reaction towards the current political crisis in Myanmar since the military coup on February $1^{\text {st }}, 2021$. Although there is a high expectation that Indonesia would go the extra mile to pressure the military government in Myanmar, President Widodo has been constrained by several domestic and international factors including his own pragmatism, the inflexibility of the attitude of Myanmar's military leaders, and China's decisive role in the whole regional situation. This may explain why the military government has a strong self-confidence to stay in power while at the same time giving the impression that it is willing to accommodate some of the aspirations of ASEAN countries. Under these political circumstances, there is not much room for President Widodo to conduct any foreign policy maneuver other than an endorsement of the normative approach that has been demonstrated by ASEAN so far. The fact that the ASEAN Leaders Meeting was conducted in Indonesia on the $21^{\text {st }}$ of April 2021 becomes an indication of how much other ASEAN members expect Indonesia's leadership in dealing with the political crisis in Myanmar. Medcalf (2020) is right in his argument that it is beyond Indonesia's capacity to handle political tensions in Southeast Asia. Being consistent with his domestic priorities and the increasing pressure to focus on handling the dramatic surge in the daily cases of COVID-19 seem to have effectively prevented President Widodo from coming up with an alternative policy in convincing the Myanmar's military leaders the importance of getting out from the current deadlock in which ASEAN's aspirations are not properly respected at all. Indonesia's tacit withdrawal from taking more initiative in actualizing its international leadership is strong evidence of how this foreign policy agenda is sensitive to the preferential option of the president himself. The situation has become more complicated for President Widodo since some leaders of ASEAN members like Thailand, Brunei Darussalam, and Cambodia tacitly support the status quo power of Myanmar's military junta leader, General Ming Aung Hlaing (Purba, 2021).

While President Widodo agrees with his predecessor that as a regional power in Southeast Asia, Indonesia should demonstrate its leadership in the field of democracy and human rights. Moreover, he also wants to show his distinct personal interpretation of such leadership by introducing new elements based on his immediate concerns and policy priorities. There are various reasons why it is arguable to say that President Widodo has developed his own interpretation of the meaning of Indonesia's leadership in the promotion of democracy and human rights. First, with the growing influence of the Islamic radical groups trying to spread the ideology of global Islamic caliphate, the president seems determined to challenge it by introducing a moderate version of Islam. As part of his campaign against Islamic radicalism which is perceived as a threat to the state ideology Pancasila, President Widodo has taken a bold decision to ban the Indonesian Hizbut Tharir. While Yudhoyono seemed to take for granted the compatibility between Islam and democracy, President Widodo takes strong initiatives to carry out an active campaign for the spread of moderate version of Islam 
with strong support from two major Islamic mass organizations NU and Muhammadiyah. Even Indonesia's humanitarian assistance for Rohingya refugees soon after the military crackdown in August 2017 was considered as a step to calm down the domestic Islamic radical groups who urged the Indonesian government to cut diplomatic ties with Myanmar and take military action.

The establishment of the Indonesian Islamic International University through Presidential Regulation No. 57/2016 is Widodo's another important initiative to contribute to the construction of an Islamic civilization which is compatible with modernity and democracy. Thus, like his predecessor, Widodo wants to assert Indonesia's leadership in promoting democracy but at the same time he is more explicit in capitalizing on Indonesia's capacity to set a model for the Islamic world as an alternative to a more radical and uncivil interpretation of the religious doctrine. On top of that, by building a university as Indonesia's vehicle to be an intellectual hub for moderate Islam, the president appears to address the criticism that Indonesian Islamic scholars have only limited influence among the Islamic world intellectuals (van Bruinessen, 2012).

Second, the success of managing its ethnic and religious diversity has made Widodo's government more confident in sharing Indonesia's experience with conflict-torn countries like Afghanistan. Therefore, when President Widodo visited Kabul in late 2017, he offered his host Indonesia's willingness to become a mediator for the conflicting parties in Afghanistan. Afghanistan President, Hamid Karzai, welcomed such idea and agreed that Indonesia would hold a dialogue as a preliminary towards a peaceful conflict resolution. As a matter of fact, Jakarta hosted the meeting of representatives of Afghanistan's different ethnic and religious groups in which dialogues were conducted to find peaceful conflict resolution that was acceptable for all parties.

Third, another important characteristic of Indonesia's pursuit of international leadership in promoting democracy under President Widodo is that he shows a strong intentionality to make Indonesian democracy capable of delivering the intention to produce for a nation with a high priority for economic development. This is the reason behind the choice of the theme "Democracy that Delivers" for the $10^{\text {th }}$ anniversary of BDF in December 2017. In fact, within three years of President Widodo's first term in office Indonesia had shown better performance in several indicators of internal bureaucratic and economic reform and manage to outrank some of its ASEAN neighbors. For instance, President Widodo had managed to improve Indonesia's rank for ease of doing business from 114 in 2014 to 72 in 2018 (World Bank, 2019). Thus, the credibility of Indonesia's projection of democratic norms to the outside world is strengthened by demonstrating that democracy can produce good governance despite the difficulties of reaching a consensus which typically characterizes the politics of decision-making process in many new democracies. Despite President Widodo's new initiative to substantiate Indonesia's promotion of democracy and human rights with additional elements such as good governance and national competitiveness, critical voices about Indonesia's limitations and weaknesses cannot just be put aside. For instance, Karim (2020) draws our attention to the fact that Indonesia's role in the United Nations Human Rights Council has been constrained by the fear that human rights violations committed by 
the Indonesian security authorities in the restive province of Papua might be raised by the international community to embarrass the Indonesian government.

\section{INDONESIA AND THE INDO-PACIFIC REGION}

How has Indonesia navigated its foreign policy in responding to the dynamics of power politics in the Indo-Pacific region over the last decade? Do President Yudhoyono and President Widodo have different foreign policy orientations in showing Indonesia's international leadership as expected by other ASEAN members? During his second term in office (2009 - 2014) President Yudhoyono and his foreign minister, Marty Natalegawa, were adamant to show Indonesia's international activism by capitalizing on the ASEAN centrality and solidity in order to neutralize the use of balance of power politics by US and China. There were at least three foreign policy initiatives indicating that under President Yudhoyono, Indonesia was quite active in substantiating its international leadership which it believed to benefit not only Indonesia's own national interests but those of the region as a whole.

First, when Indonesia held the ASEAN chairmanship in 2011, Indonesia took a leading role in the adoption of what was known to be Bali Concord III by which ASEAN declared itself as a regional community in the global community of nations. Second, in 2013 foreign minister Marty Natalegawa proposed the idea of Indo-Pacific Treaty as an alternative to balance of power politics by the great powers by emphasizing what he called a dynamic equilibrium which could ensure regional stability and security as a fundamental requirement for the maintenance of the economic momentum in the region. Third, through his shuttle diplomacy, Marty Natalegawa played an active role in mediating the conflict between Thailand and Cambodia over the control of Preah Vihear Temple. It was quite evident that Indonesia had a strong self-confidence in demonstrating its international leadership with a full support from other ASEAN members.

When President Widodo succeeded Yudhoyono in 2014, he was challenged by quite similar external environment of power politics in the Indo-Pacific region. Instead of reproducing the international activism of his predecessor, President Widodo tends to put more emphasis on the accomplishment of his domestic policy priorities. Unlike his predecessor who pursued his foreign policy goals with a great ambition, President Widodo decides to use foreign policy as his instrument for accomplishing his domestic goals. Some foreign observers even described President Widodo's approach as more inward-looking to the extent that his political regime is depicted as having the tendency of abandoning Indonesia's tradition of international leadership in Southeast Asia (Connelly, 2015). There is also a concern that in the first term of his administration, President Widodo was surrounded by foreign policy advisors and political elites who suggests that Indonesia should go beyond ASEAN to have more diplomatic space in regional and global politics (Rosyidin \& Pattipeilohy, 2020).

The research argues that it is quite misleading to suggest that Indonesia is less engaged in international politics under President Widodo's presidency. It seems more appropriate to say that Indonesia has become more critical about its own domestic interests, and it adopts an 
idea that international leadership can only be based on the solidity of its domestic foundation in terms of growing national competitiveness, massive infrastructure development throughout the country, and the national awakening from the underutilization of the nation's huge economic potentials. To say that Indonesia is less engaged in international politics under President Widodo is contrary to some concrete facts. For instance, Indonesia has managed to be elected as a non-permanent member of the UN Security Council for the period of 2019 2020. In addition, Indonesia also took a leading role to initiate the acceptance of the ASEAN Outlook on the Indo-Pacific during the $34^{\text {th }}$ ASEAN Summit in Bangkok on June $23^{\text {rd }}, 2019$ (Septiari, 2019). As far as President Widodo is concerned, the main idea behind this outlook is Indonesia's preference for an open and inclusive cooperation among countries in the region for their common prosperity. Networks of economic interdependence are expected to prevent the unnecessary escalation of power politics which could destabilize the entire region. It goes without saying that Indonesia needs such a stable and cooperative external environment to support its massive infrastructure development financed by an unhindered inflow of foreign investment.

From the very beginning since he took office in 2014, President Widodo and his foreign policy team have had real calculations on how to secure Indonesia's strategic interests amid growing tension among the great powers in the Indo-Pacific region. Thus, it was realized from the beginning that Indonesia could not stay indifferent or silent about the competing ambitions of the great powers to dominate the region. The following course of strategic events provides clear and significant evidence that great powers with their strategic stakes in the Pacific Ocean and Indian Ocean promote their respective geopolitical and geoeconomic aspirations with the effect that it is no longer relevant to talk about the two oceans as separate spatial or geographical policy entities. First, the maritime component of China's Belt and Road Initiative (BRI) requires a direct maritime connection between the Pacific Ocean and Indian Ocean through which China wants to establish networks of "policy coordination, facilities connectivity, unimpeded trade, financial integration, and people to people bonds" (The State Council the People's Republic of China, 2015). starting from China's Southeastern coastal areas down to South China Sea through the Malacca Strait on to the Indian Ocean before it reaches Africa and ultimately Europe. Countries that participate in this extensive maritime corridor may benefit from the free flow of trade commodities, industrial goods and services, capital, human resources, and technology as their economies become increasingly interdependent under China's coordination as the initiator and founder of a new kind of multilateralism. The fact that such maritime corridor cuts across the Pacific and Indian Oceans has necessitated the formation of a political geographical space within which a suitable policy framework can be proposed to make it function as China intends it to be. Thus, the cooperative response of countries in Southeast Asia and South Asia may appear to be an imperative for China so that its project of maritime connectivity can accomplish its intended goals.

Second, great powers are always sensitive to any possible change of the configuration of power in the international system. China's economic and military rise which is implied in its BRI especially the maritime component has triggered the reactions from the US, Japan, 
Australia, and India who revived the idea of Quadrilateral Security Dialogue (QSD) on the sidelines of November 2017 East Asia Summit (EAS) in Manila. Despite the peculiarity of the strategic concerns of each of these countries, they are required to formulate their strategic policies within the same regional framework of the Indo-Pacific. On top of that, these four countries are united by their traditional commitment to Western liberal democratic norms and the upholding of international laws in maintaining the global political order.

Third, in his keynote speech to the audience of the Shangri-La Dialogue hosted by the International Institute for Strategic Studies (IISS) in Singapore June 1-3, 2018, the Indian Prime Minister, Narendra Modi, suggested that he would support an open and free IndoPacific region and emphasized the importance of a rules-based regional architecture (Anjaiah, 2018). When Modi visited Jakarta before attending the Shangri-La Dialogue in Singapore, he expressed his eagerness to strengthen relationship with ASEAN especially Indonesia as an essential element of India's Act East Policy. India's intensive engagement with Southeast Asia can be considered as a strategic step to counter-balance Chinese influence in this region not only through the maritime component of China's BRI but also bilateral mechanisms that China has built with each of the ASEAN members.

While it is true that Indonesia's geopolitical aspiration to make a projection of its ideational resources in the formation of a new regional architecture in the Indo-Pacific region was initially announced during the era of President Yudhoyono, the contention of the research is that President Widodo's foreign policy has gone beyond just an imitation of what has been done before. It is argued that the current government has been active in embedding Indonesia's own national interests into its geopolitical strategy while, at the same time, capitalizing on the importance of regional mediatory mechanisms that cannot be easily dismissed by any great power of the Indo-Pacific region. Under President Widodo, Indonesia is fully aware of the fact that the intensity of the rivalry among great powers in the IndoPacific region will only reaffirm the necessary role of a regional or middle power with diplomatic credentials capable of reaching out to all stakeholders in the region. Indonesia also seems to capitalize on its positional flexibility to harness or embark on its own foreign policy maneuver by instrumentalizing the zero-sum game environment created by the rivalry among great powers who lock themselves in their respective exclusivity, and demand for a stability and security for the whole region.

In analyzing Indonesia's initiative of international leadership as a regional power, the research does not limit the discussion on the application of the variables proposed by Flemes and Wojczewski (2011) but goes further by looking at how President Widodo and his Foreign Minister, Retno L.P. Marsudi, strategize by combining the external opportunities and internal capabilities for the accomplishment of Indonesia's foreign policy objectives. The president himself is adamant about making his foreign policy serve the best interests of his domestic priorities. There is a conscious effort by the president and his foreign policy team to reveal a predisposition that Indonesia's assertion of international leadership is not meant to be part of an impression management project, but it is connected to the real interests of the nation. Such predisposition is needed because under President Yudhoyono, there was an accusation that Indonesia's international activism was not balanced by internal efforts to address many 
unresolved problems including corruption among the ruling party, religious radicalism and terrorism, persecution of minority groups, and bureaucratic inefficiency from the central government down to the regional level. Skeptical voices about Indonesia's emergence as a leading power in Asia referred to these internal weaknesses as the reason why Indonesia "punches below its weight" in international affairs (Reid, 2012).

President Widodo has brought ways to connect his domestic policy priorities and Indonesia's foreign policy towards the Indo-Pacific region. First, there is no doubt that the formation of Indo-Pacific region through the dynamics of international politics among great powers has stimulated responses from countries whose strategic interests are affected by such policy discourse. Under President Widodo, Indonesia has come up with the grand strategy of describing itself as a global maritime axis in line with the archipelagic nature of the country and an intentionality to contribute to the stability and security of the Indo-Pacific region. President Jokowi realizes that geographically the Pacific and Indian oceans are connected through the Indonesian territorial waters and obviously Indonesia feels the pressure to find ways how to secure its maritime sovereignty from any external potential threat. Thus, Indonesia's self-declaration as a global maritime fulcrum has two interrelated objectives. At the external level, Indonesia's assertion as a global maritime fulcrum a preliminary step towards a subsequent announcement of a plan to initiate an Indo-Pacific cooperation. From a domestic perspective, Indonesia wants to substantiate its claim as a maritime power by building inter-island connectivity for the sake of a more efficient commercial interactions and other economic activities. The combination of good maritime infrastructures and modernization of Indonesian navy is expected to eventually strengthen Indonesia's maritime sovereignty and the capacity to manage maritime resources with the mobilization of foreign resources through the cooperation that Indonesia has decided to initiate.

Second, Indonesia's unique position with no significant conflict with any great power enables it to strengthen relationship with all of them without sacrificing its credentials as a provider of mediatory services when circumstances demand such role. With such unique position, Indonesia has the flexibility of reaching out to build strategic relationship with them while at the same time inviting them to supply financial resources required for developing its infrastructures. Currently, Indonesia is cooperating with China to build the Jakarta - Bandung high speed train while inviting Japan to support the development of deep seaport at Patimban to the east of Tanjung Priok. In a move that seems to balance China's maritime domination from South China Sea down to the Indian Ocean through the Malacca Strait, Indonesia has offered the building of Sabang port project to India whose current Act East Policy requires an intensive engagement with ASEAN member countries. Indonesia's multi-direction search for foreign investment in the Indo-Pacific region for the financing of its infrastructure projects turns out to be in line with its initiative to create a cooperative and peaceful architecture of diplomacy within the framework of the ASEAN Outlook on the Indo-Pacific. This is also an indication that President Joko Widodo interprets the independent and active foreign policy principle in a very pragmatic way.

Third, it stands to reason to say that the bilateral relationship between India and Indonesia constitutes an important element of the whole construction of a new Indo-Pacific 
regional architecture. As a regional power, Indonesia welcomes India's intention to strengthen its relations with ASEAN members. Thus, when Indian Prime Minister, Narendra Modi, came to Jakarta in June 2018, President Widodo welcomed him with great enthusiasm and the two leaders agreed to take their bilateral relations to a higher level considering the complementarity and interdependence between the two economies. On top of that, both India and Indonesia are key members of the Non-aligned Movement with a strong foreign policy tradition of resisting against the use of power politics for hegemonic purposes. As far as India is concerned, its increasing engagement with Indonesia and other ASEAN members is required to balance China's hegemonic power and military assertiveness in South China Sea as the starting point of its BRI's maritime global connectivity. Thus, as a result of his meeting with President Widodo, Prime Minister Modi gave his support to Indonesia's initiative for an open and inclusive Indo-Pacific cooperation. Not only did Indonesia gain India's support for its global maritime fulcrum policy, but President Widodo also asked his guest to lower tariffs for Indonesia's Crude Palm Oil (CPO) export (Anjaiah, 2018). The incorporation of economic diplomacy in the navigation of Indonesia's foreign policy with the great powers in the IndoPacific region is part of the strategy to utilize external opportunities as well as to capitalize on domestic potentials for the accomplishment of foreign policy objectives.

Finally, Indonesia's initiative to promote the Indo-Pacific cooperation has a distinctive characteristic that it underlines the importance of international peace, regional stability, and common prosperity. Course of events before the announcement of such initiative may strongly indicate that Indonesia is on the move to expand the diplomatic arena in which the integrity of the UNCLOS principles can be defended not only for the sake of Indonesia's own maritime sovereignty but also the imperative of a bigger pressure to prevent China from violating further international laws after establishing military infrastructures in the disputed islands of South China Sea. With the increasing difficulty of uniting different and conflicting policies of ASEAN members in dealing with the territorial disputes in South China Sea and China's tendency to instrumentalize their economic dependence on China's investment and market access, Indonesia is under mounting pressure to find alternatives in addition to its traditional reliance on the collective decisions produced in ASEAN summits. Moreover, ASEAN countries was said to be lacking in turning their collective commitment into real actions or projects to resolve their common problems (Agastia, 2021).

Under President Widodo, Indonesia has come to realize that there must be a diplomatic mechanism to change the narrative of balance of power that is preferred by the great powers into what former Indonesian Foreign Minister Marty Natalegawa called "a dynamic equilibrium". On its own, ASEAN cannot persuade China to adopt such policy narrative as it needs wider mechanisms like East Asia Summit (EAS) and its Treaty of Amity and Cooperation (TAC) which are strong enough as common platforms to formulate decisions acceptable to all great powers including China. This is what Indonesia has in mind when it seeks to maintain the centrality of ASEAN within the framework of Indo-Pacific cooperation.

There is no doubt that China would give highest priority to the implementation of the maritime connectivity of its BRI. Despite China's obvious preference for the success of its BRI, Beijing cannot easily sacrifice its strategic relations with ASEAN, otherwise it would 
run the risk of losing its legitimacy in Asia. The US Defense Minister James Mattis made harsh criticisms against China's "intimidation and coercion" in South China Sea during the $17^{\text {th }}$ Shangri-la Dialogue in Singapore (Anjaiah, 2018). In response, Hangtian, spokesperson of the Chinese Embassy in Jakarta wrote a letter to the editor of The Jakarta Post complaining that the US only made "sensationalization" in South China Sea while at the same time pointing out Beijing's strong emphasis on the solidity of bilateral relations between China and ASEAN member countries (Anjaiah, 2018). It is quite evident that on one hand China wants to embrace ASEAN as its cooperative dialog partner in dealing with the territorial disputes in South China Sea, and on the other hand it resists any interference from the outside especially by the US. China's ambiguity in dealing with ASEAN countries can be made more complicated by the fact that under President Xi Jinping, China tends to be quite assertive in its security policy especially regarding the territorial dispute in South China Sea (Sinaga, 2020).

It seems too early to say with certainty how Indonesia will follow up the acceptance of the ASEAN Outlook on the Indo-Pacific. Indonesia has used not only state to state diplomacy but also the regional platform of ASEAN to gain support from all the stakeholders including the great powers. The optimal use of the existing ASEAN mechanisms would probably the best way to gather all the great powers, in which they can have a common platform to conduct dialogue than to pursue power politics with its destabilizing effect. The great powers have continued to frame their strategic policies based on their respective geopolitical aspirations related to the emergence of the Indo-Pacific region. Hence it seems that the discursive effect of the regional dynamics both on policy level and the epistemic communities cannot be put aside as the stakes are real, and the political ramifications are clearly recognized. It remains to be seen how Indonesia would navigate its international leadership in promoting the IndoPacific cooperation despite the opportunities to start the discussion and dialogue based on the common interests of all the stakeholders.

The research may see the prospect of international politics of the Indo-Pacific region in the post-pandemic COVID-19. It seems that all countries in the region focus on the domestic management of the crisis and try to cope with the likelihood of economic downturn at the regional and national level. As far as Indonesia is concerned, the priority of pushing forward the agenda of economic growth in the post-pandemic era seems non-negotiable. In this context, it might be helpful to strategize new innovations in the conduct of Indonesia's economic diplomacy by recalibrating Indonesia's enormous potential in the rapidly growing digital economy in this region (Margiansyah, 2020). In interpreting the meaning of Indonesia's regional leadership in ASEAN, President Widodo never puts aside the fact that Indonesia is competing with other ASEAN countries especially in maximizing the economic opportunities that come along with the rise of China. On top of that, in ending his second term in power in 2024, the President makes sure that his performance legitimacy is secured through a smooth economic recovery and the creation of regional stability. The current extending and deepening bilateral cooperation with China in trade and investment appears to be an imperative. As a result, whatever policy Indonesia will take in dealing with the contestation of great powers in the Indo-Pacific region, it will be navigated in a pragmatic way in order not to run the risk of damaging the momentum of bilateral cooperation with China. It remains to be 
seen how far such pragmatism will affect Indonesia's principle of independent and active foreign policy since getting too close to China would spark a domestic reaction from the nationalist groups and opposition parties in the parliament.

\section{CONCLUSIONS}

When President Widodo came to power in 2014, he was widely perceived as an inward-looking leader without a clear vision of what to do with his foreign policy. There was a speculation that he would abandon Indonesia's international activism that had characterized the foreign policy of his predecessor President Yudhoyono. The research has tried to challenge this allegation by arguing that, as a matter of fact, President Widodo has a different conceptualization of what Indonesia should do with this tradition of international leadership. Thus, the role of an individual state leader matters in understanding Indonesia's international leadership. Two important foreign policy agendas, namely the promotion of democracy and human rights and the acceptance of the ASEAN Outlook on the Indo-Pacific, have been selected to see how the two presidents demonstrate Indonesia's international leadership. The use of the concept of international leadership in this research includes initiatives, namely the promotion of ideational resources as a normative orientation in the organization of interactions among states, setting good examples that are worthy of emulation by other countries, and the use of dialogue instead of coercive power in resolving international conflicts.

As Indonesia's first democratically elected president, Yudhoyono was aware that under his leadership Indonesia needed to build a new international identity as a democratic country and would leave behind the era of authoritarianism that had been tainted by massive violations of human rights. With the establishment of Bali Democracy Forum (BDF) in 2008, Yudhoyono set an international stage not only for Indonesia but also himself to convince the international community that Indonesia had some credentials to introduce a more egalitarian efforts in spreading the universal principles of democracy and human rights. President Yudhoyono himself was actively engaged in telling his international audience that Indonesia had managed to demonstrate that Indonesian moderate version of Islamic religion was compatible with modern democracy. The experience could be offered to the Islamic world, especially in the Middle East where people were struggling to combine religious piety with political civility. At the regional level, President Yudhoyono took the initiative to make ASEAN recognized as a regional entity capable of contributing positively to global peace and security. Thus, when Indonesia held ASEAN's chairmanship in 2011, President Yudhoyono proposed the idea of Bali Concord III by which the regional organization declared itself as a reliable partner in the global community of nations. It is quite evident that President Yudhoyono's international activism had used idealistic approach in promoting Indonesia's international leadership with a rather loose connection to his domestic policies. Consequently, his critics accused him of being too much preoccupied with impression management overseas while neglecting to address some critical issues at home like corruption eradication and the protection of the minority rights. 
At the beginning of his presidency, President Widodo created a strong impression that he would abandon international activism and focus more on his domestic priorities. It has been shown that the President remains committed to carry out its agenda of international leadership, but it is strongly connected to the accomplishment of Indonesia's own national interests. Indonesia has been successfully elected as a non-permanent member of the UN Security Council, and has held leading role in the acceptance of the ASEAN Outlook on the Indo-Pacific. It is used as evidence of how President Widodo attempts to create a balance between his domestic policy priorities and Indonesia's international responsibilities. The concept of international leadership by Destradi corresponds to what President Widodo has done in his foreign policy by which Indonesia capitalizes more on the mobilization of ideational resources than material capabilities. While President Yudhoyono tends to rely on his idealistic approach in promoting Indonesia's international leadership, President Widodo prefers to use a more pragmatic approach in the sense that the consideration of Indonesia's national interests should come first. Therefore, when Indonesia promotes democracy to the world, the President wants to convince his international audience that Indonesian democracy is also capable of delivering good governance, national competitiveness, and poverty eradication. Indonesia's endeavor for the acceptance of the ASEAN Outlook on the IndoPacific is not without its strong connection with some domestic strategic needs. There is a functional connection between Indonesia's initiative of the Indo-Pacific cooperation and its declaration of the archipelago as a global maritime fulcrum whose realization requires a mobilization of financial resources from the great powers like US, China, Japan, and India. There is also a systematic diplomacy to promote export of CPO to China and India as alternative markets since US and European Union continue to instrumentalize environmental reasons in reducing export of Indonesia's strategic commodity. The fact that the global spread of COVID-19 has increased tension between US and China should point to the importance of the ASEAN Outlook on the Indo-Pacific with its emphasis on the mechanism of dialogue and mutual respect for the benefit of all stakeholders in the region. In conclusion, the research has demonstrated that Indonesia's international leadership is very much contingent upon individual preferences of the presidents in both formulating their policies and their implementation.

\section{ABOUT THE AUTHORS}

Prof. Aleksius Jemadu is a lecturer of International Relations Department, Pelita Harapan University. His research interest are about global politics, corporate and international security, and the Indo-Pacific region. He has published journals and books focusing on the study of International Relations.

Floranesia Lantang is a lecturer of International Relations, Pelita Harapan University. She received her Master of National Security Policy from the Australian National University. Her research interests include non-traditional security, border management, Papua, and Indonesia-Australia relations. 


\section{REFERENCES}

Acharya, A (2014). Indonesia's Matter: Asia's Emerging Democratic Power. London: World Scientific Publishing Company.

Agastia, I. G. B. D. (2021). Maritime security cooperation within the ASEAN institutional framework: A gradual shift towards practical cooperation. Journal of ASEAN Studies, 9(1), 25-48. https://doi.org/10.21512/jas.v9i1.6919.

Alexandra, L. \& Basuki, T. (2014). Democracy, human rights and Indonesia's foreign policy under Yudhoyono, The Indonesian Quarterly, 42(3-4), 183 - 200.

Anjaiah, V. (2018, June 04). China intimidating neighbor, US Says. The Jakarta Post. https://www.thejakartapost.com/news/2018/06/04/china-intimidating-neighbors-ussays.html

Beasley, R. K., Kaarbo, J., Lantis, J. S., \& Snarr, M. T. (2013). Foreign Policy in Comparative Perspective: Domestic and International Influence on State Behavior ( $2^{\text {nd }}$ Ed.). SAGE Publication, Inc.

Breslin, S. (2017). Leadership and followership in post-unipolar world: Towards selective global leadership and a new functionalism? Chinese Political Science Review, 2, 494511. https://doi.org/10.1007/s41111-017-0082-y

Breuning, M. (2007). Foreign Policy Analysis: A Comparative Introduction. New York: Palgrave Macmillan

Buzan, B. (2013). The Asia-Pacific: What sort of region in what sort of world? In A. McGrew and C. Brook (Eds.), Asia-Pacific in the New World Order (pp. 68-87). Abingdon: Routledge.

Connelly, A. L. (2015). Sovereignty and the sea: President Joko Widodo's foreign policy challenges. Contemporary Southeast Asia, 37(1), 1-28. https://doi.org/10.1355/cs37-1a

Dermawan, W., Purnama, C., \& Mahyudin, E. (2019). Indonesia foreign policy in the era of Susilo Bambang Yudhoyono (2004-2014) towards Myanmar in supporting democratization. Jurnal Hubungan Internasional, 11(2), 264-277. http://dx.doi.org/10.20473/jhi.v11i2.10500

Destradi, S. (2010). Regional powers and their strategies: Empire, hegemony, and leadership. $\begin{array}{llll}\text { Review of International Studies, 36(4), 903-930. } & \text { 36 }\end{array}$ https://doi.org/10.1017/S0260210510001361

Flemes, D. \& Wojczewski, T. (2011). Contested leadership in International relations: Power politics in South America, South Asia, and Sub-Saharan Africa. GIGA Working Paper No. 121. GIGA German Institute of Global and Area Studies. https://doi.org/10.2139/ssrn.1547773 
Howard, P. (2010). Triangulating debates within the field: Teaching International relations research methodology. International Studies Perspective, 11(4), 393-408. https://doi.org/10.1111/j.1528-3585.2010.00413.x

Karim, M. F. (2016). Role conflict and the limits of state identity: The case of Indonesia in democracy promotion. The Pacific Review, 30(3), 385-404. http://dx.doi.org/10.1080/09512748.2016.1249908.

Karim, M. F. (2020). The limits of global human rights promotion: Indonesia's ambivalent roles in the UN Human Rights Council. Contemporary Politics, 26(3), 351-370. https://doi.org/10.1080/13569775.2020.1720065.

Karim, M. F. (2021). Role legitimation in foreign policy: The case of Indonesia as an emerging power under Yudhoyono's presidency. Foreign Policy Analysis, 17(3). http://doi.org/10.1093/fpa/orab010

Kobierski, L. (2021, March 17). China's reaction to the march meeting of quad. Warsaw Institute. https://warsawinstitute.org/chinas-reaction-march-meeting-quad/

Mahbubani, K. \& Kee, J. S. H. (2018). The ASEAN Miracle: A Catalyst for Peace. NUS Press. https://doi.org/10.2307/j.ctv1xz0m3

Margiansyah, D. (2020). Revisiting Indonesia's economic diplomacy in the age of disruption: Towards digital economy and innovation diplomacy. Journal of ASEAN Studies, 8(1), 15-39. https://doi.org/10.21512/jas.v8i1.6433.

Medcalf, R. (2020). Contest for the Indo-Pacific: Why China Won't Map the Future. Melbourne: La Trobe University Press.

Mintz, A. \& DeRouen Jr, K. (2010). Understanding Foreign Policy Decision Making. New York: Cambridge University Press.

Nabers, D. (2010). Regional Leadership in the Global System: Ideas, Interest, and Strategies in Regional Power. Burlington: Ashgate Publishing.

Purba, K. (2021, August 09). Thai PM perfect role model for Myanmar's junta leader. The Jakarta Post. https://www.thejakartapost.com/paper/2021/08/09/thai-pm-perfect-rolemodel-for-myanmars-junta-leader.html

Reid, A (Eds.). (2012). Indonesia Rising: The Repositioning of Asia's Third Giant. Singapore: Institute of Southeast Asian Studies. https://doi.org/10.1080/03068374.2013.795375

Roberts, C. B., Habir, A. D., \& Sebastian, L. C. (Eds.). (2015). Indonesia's Ascent: Power, Leadership, and the Regional Order. Palgrave Macmillan UK. https://doi.org/10.1057/9781137397416

Rosyidin, M. \& Pattipeilohy, S. C. H. (2020). Regionalism under challenge: Ideas and Joko Widodo's foreign policy towards ASEAN, 2014-2019. Journal of ASEAN Studies, 8(2), 148-172. https://doi.org/10.21512/jas.v8i2.6596. 
Septiari, D. (2019, June 23). ASEAN leaders adopt Indonesia led-Indo-Pacific Outlook. The Jakarta Post. https://www.thejakartapost.com/seasia/2019/06/23/asean-leaders-adoptindonesia-led-indo-pacific-outlook.html

Sinaga, L. C. (2020). Xi Jinping, "China Dream", and Chinese military diplomacy to ASEAN. Journal of ASEAN Studies, 8(2), 174-190. https://doi.org/10.21512/jas.v8i2.6483.

Shekhar, V. (2018). Indonesia's Foreign Policy and Grand Strategy in the 21st Century: Rise of an Indo-Pacific Power ( ${ }^{\text {st }}$ Ed.). London: Routledge. https://doi.org/10.4324/9781315560977

Suryadinata, L. (1996). Indonesia's Foreign Policy Under Suharto: Aspiring to International Leadership. Singapore: Times Academic Press. https://doi.org/10.2307/2646613

The State Council the People's Republic of China (2015). Full text: Action plan on the belt and road initiative. English. Gov. Cn. http://english.www.gov.cn/archive/publications/2015/03/30/content_28147508024903 5.htm\#: : text=The $\% 20$ Belt $\% 20$ and $\% 20$ Road $\% 20$ Initiative $\% 20$ aims $\% 20$ to $\% 20$ promot e $\% 20$ the $\% 20$ connectivity,connectivity $\% 20$ networks $\% 2 \mathrm{C} \% 20$ and $\% 20$ realize $\% 20$ diver sified $\% 2 \mathrm{C}$

van Bruinessen, M. (2012). Indonesian Muslims and their place in the larger world of Islam. In A. Reid (Eds.), In Indonesia Rising: The Repositioning of Asia's Third Giant (pp. 117-140). Singapore: Institute of Southeast Asian Studies.

Viotti, P. R. \& Kauppi, M. V. (2014). International Relations Theory $\left(5^{\text {th }}\right.$ Ed.). Illinois: Pearson Education, Inc.

World Bank. (2019). Rankings \& ease of doing business score. https://www.doingbusiness.org/en/rankings. 